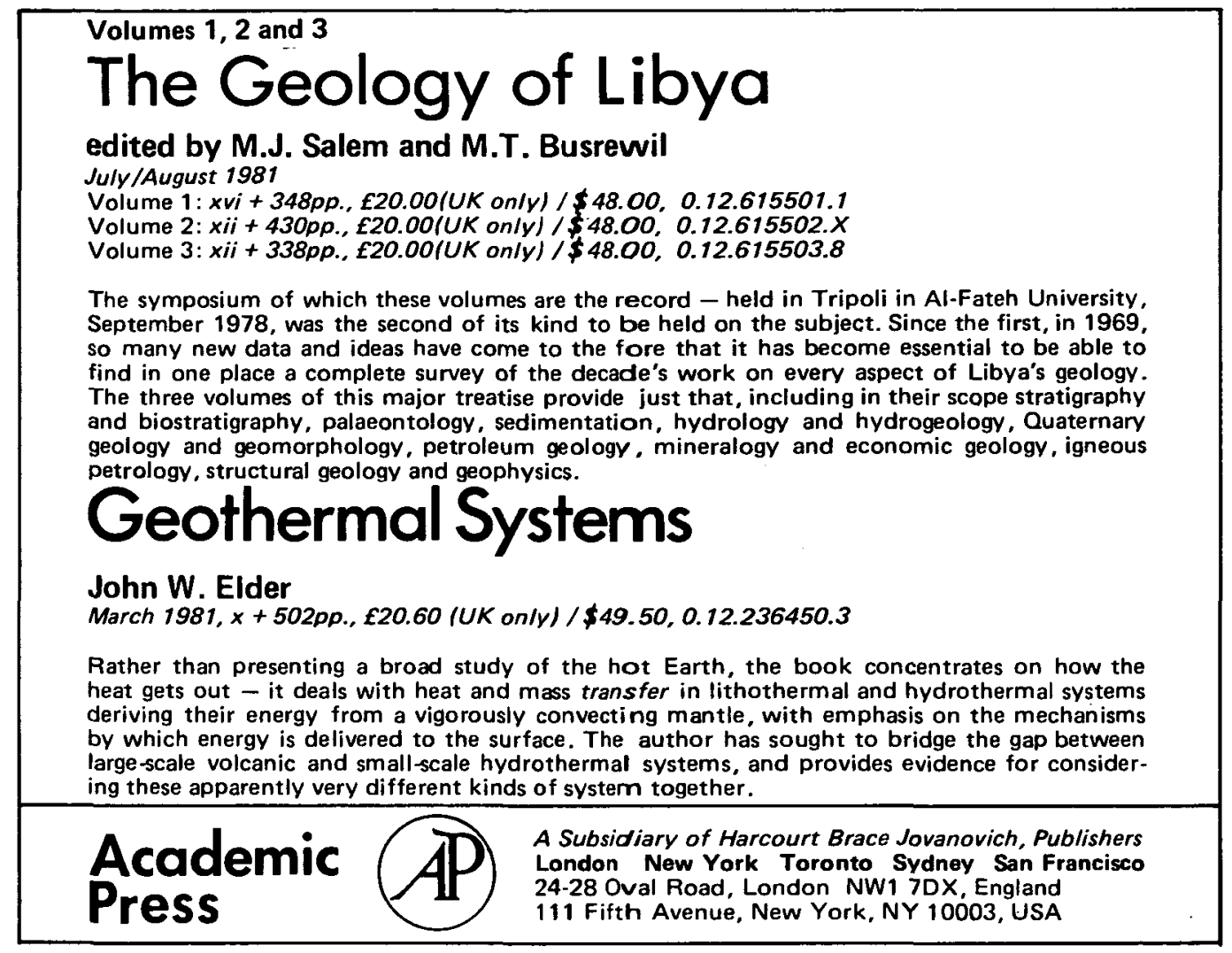



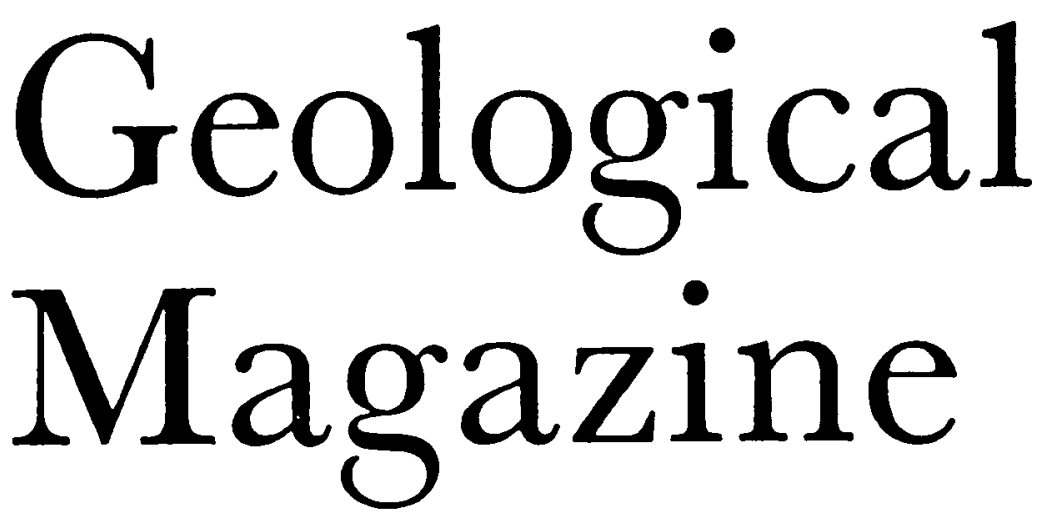

with which is incorporated

\section{The Geologist}

founded in 1864 by the late DR HENRY WOODWARD, F.R.S.

Edited by W. B. HARLAND, M.A.

C. P. HUGHES, M.A.

and R. S. J. SPARKS, M.A.

assisted by MRS M. J. MASON

Associate editors

SIR KINGSLEY DUNHAM, D.SC., F.R.S.

MR N. L. FALCON, M.A., F.R.S.

PROFESSOR LEONARD HAWKES, D.SC., F.R.S.

SIR PETER KENT, D.SC., F.R.S.

DR S. R. NOCKOLDS, PH.D., F.R.S.

PROFESSOR F. W. SHOTTON, M.B.E., M.A., SC.D., F.R.S.

SIR JAMES STUBBLEFIELD, D.SC., F.R.S.

\section{Volume I 8 of Whole Series}

January-December I98I

\section{CAMBRIDGE UNIVERSITY PRESS \\ CAMBRIDGE \\ LONDON NEW YORK NEW ROCHELLE \\ MELBOURNE SYDNEY}


PUBLISHED BY

THE PRESS SYNDICATE OF THE UNIVERSITY OF CAMBRIDGE

The Pitt Building, Trumpington Street, Cambridge CB2 IRP

32 East 57 th Street, New York, N.Y. 10022

(C) Cambridge University Press 1981

Pagination and dates of publication of issues in this volume

Number 1: pp. 1-112 January 1981

2: pp. 113-224 March 1981

3: pp. 225-336 May 1981

4: pp. $337-448$ July 1981

5: pp. 449-579 September 1981

6: pp. 581-722 November 1981

Printed in Great Britain at the University Press Cambridge 


\section{Contents}

\section{ARTICLES}

(Figures in bold type denote number of issue)

ADIGHIJE, C. I.

Gravity study of Lower Benue Trough, Nigeria, 1, 59

BAHAT, Dov.

Certain mechanical aspects in comparative continental rifting with a special reference to the Baikal rift, 3, 271

BAKER, S. J.

The graptolite biostratigraphy of a Llandovery outlier near Llanystumdwy, Gwynedd, North Wales, 4, 355

BANHAM, P. H., HOPPER, F. M. W. \& JACKSON, J. B.

The Gillbrea Nappe in the Skiddaw Group, Cockermouth, Cumbria, England, 5, 509

BASSETT, M. G.

The Ordovician brachiopods of Cornwall, 6, 647

BENTON, M. J. \& WALKER, A. D.

The use of flexible synthetic rubbers for casts of complex fossils from natural moulds, 5,551

BHAT, M. I., ZAINUDDIN, S. M. \& RAIS, A.

Panjal Trap chemistry and the birth of Tethys, 4, 367

BLACKBOURN, G. A.

Correlation of Old Red Sandstone (Devonian) outliers in the Northern Highlands of Scotland, 4, 409

BUTLER, D. E.

Marine faunas from concealed Devonian rocks of southern England and their reflection of the Frasnian transgression, 6, 679

CALVER, M. A.

Palaeozoic studies in honour of Sir James Stubblefield, 6, 581

DALZIEL, I. W. D., ELLIOT, D. H., JONES, D. L., THOMSON, J. W., THOMSON, M.R.A., WELLS, N. A. \& ZINSMEISTER, W. J.

The geological significance of some Triassic microfossils from the South Orkney Islands, Scotia Ridge, 1, 15

DUYVERMAN, H. J. \& ROOBOL, M. J.

Gas pipes in Eocambrian volcanic breccias, 3, 265

EVANS, K. M.

A marine fauna from the Dartmouth Beds (Lower Devonian) of Cornwall, 5, 517

FORTEY, R. A.

Prospectatrix genatenta (Stubblefield) and the trilobite superfamily Cyclopygacea, 6, 603

GALE, A. S. \& WOODROOF, P. B.,

A Coniacian ammonite from the 'Top Rock' in the chalk of Kent, 5, 557

GOMEZ, B. \& SIMS, P. C.

Overbank deposits of the Narrator Brook, Dartmoor, England, 1, 77 
GRAHAM, C. M. \& BRADBURY, H. J.

Cambrian and late Precambrian basaltic igneous activity in the Scottish Dalradian: a review, 1, 27

HANCOCK, P. L., AL-KHATIEB, S. O. \& AL-KADHI, A.

Structural and photogeological evidence for the boundaries to an East Arabian block, 5,533

HIGGINS, A. C. \& SOPER, N. J.

Cretaceous-Palaeogene sub-basaltic and intrabasaltic sediments of the Kangerdlugssuaq area, Central East Greenland, 4, 337

HINDLE, W. H. \& COLLEY, $H$.

An oceanic volcano in an island-arc setting - Seatura Volcano, Fiji, 1, 1

HOARE, P. G. \& CONNELL, E. R.

The chalky till at Barrington, near Cambridge, and its connection with other Quaternary deposits in southern Cambridgeshire and adjoining areas, 5, 463

HOJJATZADEH, M.

Mid-Cretaceous (Albian-Cenomanian) calcareous nannofossils from Pont du Fahs (northern Tunisia), 2, 161

HOU, HONG-FEI.

Devonian brachiopod biostratigraphy of China, 4, 385

JARVIS, I. \& WOODROOF, P.

The phosphatic chalks and hardgrounds of Boxford and Winterbourne, Berkshire - two tectonically controlled facies in the late Coniacian to early Campanian (Cretaceous) of southern England, 2, 175

JOHNSON, M. R. W.

The erosion factor in the emplacement of the Keystone thrust sheet (South East Nevada) across a land surface, 5, 501

KANTHA, L. H.

'Basalt fingers' - origin of columnar joints?, 3, 251

LAMBERT, R. St J., WINCHESTER, J. A. \& HOLLAND, J. G.

Comparative geochemistry of pelites from the Moinian and Appin Group (Dalradian) of Scotland, 5, 477

LEITCH, E. C.

Quartz-albite rocks of ash-fall origin, 1, 83

MAJIDI, B.

The ultrabasic lava flows of Mashhad, North East Iran, 1, 49

MASON, R.

A trondhjemite vein in the Sulitjelma Gabbro, Norway, and its implications for the age of the Sulitjelma Ophiolite, 5, 525

MAYALL, M. J.

The Late Triassic Blue Anchor Formation and the initial Rhaetian marine transgression in south-west Britain, 4, 377

MITCHELL, $M$.

The age of the Dinantian (Lower Carboniferous) rocks proved beneath the Kent Coalfield, 6, 703 
MITCHELL, M. \& REYNOLDS, M. J.

Early Tournaisian rocks at Lilleshall, Shropshire, 6, 699

OLAUSSEN, $\mathrm{S}$.

Marine incursion in Upper Palaeozoic sedimentary rocks of the Oslo Region, Southern Norway, 3, 281

OWENS, R. M.

The Ordovician proetacean trilobite Rorringtonia, 1, 89

P'AN, K.

Devonian Antiarch Biostratigraphy of China, 1, 69

PAUL, D. K. \& POTTS, P. J.

Rare earth abundances and origin of some Indian lamprophyres, 4, 393

PICCARRETA, G.

Deep-rooted overthrusting and blueschistic metamorphism in compressive continental margins. An example from Calabria (Southern Italy), 5, 539

PRICE, D.

Tretaspis radialis Lamont and allied species (Trilobita), 3, 289

ROBERTS, B.

Low grade and very low grade regional metabasic Ordovician rocks of Llŷn and Snowdonia, Gwynedd, North Wales, 2, 189

ROBINSON, D.

Metamorphic rocks of an intermediate facies series juxtaposed at the Start boundary, southwest England, 3, 297

ROCK, N. M. S.

How should igneous rocks be grouped?, 5, 449

ROTHSTEIN, A. T. V.

The primary crescumulates of the Lizard peridotite, Cornwall, 5, 491

RUSHTON, A. W. A.

A polymorphic graptolite from concealed Tremadoc rocks of England, 6, 615

RUSHTON, A. W. A. \& HUGHES, C. P.

The Ordovician trilobite fauna of the Great Paxton Borehole, Cambridgeshire, 6, 623

SHAKESBY, R. A.

The application of trend surface analysis to directional data, 1, 39

SHEARMAN, D. J.

Displacement of sand grains in sandy gypsum crystals, 3, 303

SMELLIE, J. L.

A complete arc-trench system recognized in Gondwana sequences of the Antarctic Peninsula region, 2, 139

SOLIMAN, M. M.

Geochemical surveys for $\mathrm{Sn}, \mathrm{Nb}, \mathrm{Cu}$ and $\mathrm{Au}$ mineralization, Mueilha - Dungash area, Southeastern Desert, Egypt, 5, 545

SWETT, $K$.

Cambro-Ordovician strata in Ny Friesland, Spitsbergen and their palaeotectonic significance, 3, 225 
TRIPP, R. P. \& EVITT, W. R.

Silicified Lichidae (Trilobita) from the Middle Ordovician of Virginia, 6, 665

WARE, M. \& WINDLE, T. M. F.

Micropalaeontological evidence for land near Cirencester, England, in Forest Marble

(Bathonian) times: a preliminary account, 4, 415

WHITTINGTON, H. B.

Paedomorphosis and cryptogenesis in trilobites, 6, 591

WILLIAMS, $\mathbf{S}$. $\mathrm{H}$.

Form and mode of life of Dicellograptus (Graptolithina), 4, 401

YANG, S., P'AN, K. \& HOU, H.

The Devonian System in China, 2, 113

ZHANG, Z.

A new Oscillatoriaceae-like filamentous microfossil from the Sinian (late Precambrian) of western Hubei Province, China, 2, 201

\section{CORRESPONDENCE}

ACHARYYA, S. K. Alkaline $v$. calc-alkaline Late Palaeozoic volcanism in the Himalayas and some aspects on Himalayan geotectonics, 4, 421

ALLEN, P. M. A new occurrence of possible Tertiary deposits in South-western Dyfed, 5,561

COPE, J. C. W. The Swansea Valley Fault, Wales, 3, 309

HOLMES, J. \& SCOTT, A. C. A note on the occurrence of marine animal remains in a Lancashire coal ball (Westphalian A), 3, 307

JAMES, D. M. D. Petrographic evidence bearing on plate tectonics of the Upper Ordovician Welsh Basin, 1, 95

TAVENER-SMITH, R. The neotype of Retepora nodulosa Phillips, 1836, 5, 565

WHITE, D. E. The base of the Ludlow Series in the graptolitic facies, 5, 566

WRIGHT, V. P. A subaerial stromatolite from the Lower Carboniferous of South Wales, 1,97

\section{ESSAY REVIEWS}

BAILEY, D. K. Bowen and the Post-Impressionists, 3, 311

HARLAND, W. B. Introducing New Zealand Geology, 5, 567

HAZEN, R. M. A Bibliography for Historians of Geology, 4, 425

\section{REVIEWS}

The Age of the Earth, 2, 221

Archaean volcanic studies in the Timmins-Kirkland Lake-Noranda region of Ontario and Quebec, 4, 431

Atlas of Primitive Man in China, 4, 441

Atlas of rock-forming minerals in thin section, 1, 106

Atmospheric Phenomena, 2, 218 
Beitrage zur regionalen Geologie der Erde, 4, 433

The Biosaline Concept. An approach to the Utilization of Underexploited Resources, 6, 713

British Brachiopods, 2, 213

The Cambridge Encyclopedia of Archaeology, 1, 106

Chemistry and Biogeochemistry of Estuaries, 4, 435

A Comparison of two Atlantic-type continental margins, 3, 332

A Concise World Atlas of Geology and Mineral Deposits, 4, 436

Cretaceous Research Volume 1, Number 1, 1, 107

Deltaic Sand Bodies, 3, 327

Diagenesis in Sediments and Sedimentary Rocks, 3, 319

Dictionary of Earth Science. English-French: French-English, 3, 324

Early Diagenesis: A Theoretical Approach, 3, 330

The Earth: Past, Present and Future. An Introduction to Geology, 3, 320

Earthquake Prediction and Seismicity Patterns, 3, 321

Earthquakes, 4, 432

Energy in Transition 1985-2010. Final Report of the Committee on Nuclear and Alternative Energy Systems, 2, 215

Estimation of Minimum Specitications for Economically Explorable Sandstone-Type uranium Deposits. 4, 429

Estuarine and Wetland Processes with emphasis on Modelling, 6, 714

Estuarine Hydrography and sedimentation, 2, 207

The Evidence for Chemical Heterogeneity in the Earth's Mantle, 3, 329

The Evolution of Passive Continental Margins in the Light of Recent Deep Drilling Results, 3, 322

Experimental photogrammetry of Lunar Images. Apollo 15-17 orbital investigations, 2, 211 Fjord Oceanography, 6, 713

The Fossil Hunters. In Search of Ancient Plants, 5, 571

Fossils in the making. Vertebrate Taphonomy and Paleoecology, 1, 103

General Geology of the Federal Republic of Germany, with Two Excursions to Industrial Mineral Rocks and Environmental Research, 4, 434

Geochemistry of Hydrothermal Ore Deposits, 2, 209

Geological Howlers, 6, 715 .

A geological map of Ethiopia and Somalia (1973) $1: 2,000,000$ and comment with a map of Major Landforms, 3, 322

Geology and Scenery in Scotland, 2, 207

Geology of Bideford and Lundy Island, 5, 574

The Geology of Europe, 5, 575

The Geology of Guadalcanal, Solomon Islands, 2, 210

Geology of the country around Bude and Bradworthy (Sheet Memoir 307 \& 308), 1, 105

Geology of the country around Chulmleigh (Sheet Memoir 309), 1, 105 
Geology of the country north of Derby, 4, 439

Geology. The Science of the Earth, 2, 220

Geometric interpretation of lunar craters. Apollo 15-17 Orbital Investigations, 3, 328

Ground Water, 2, 208

Groundwater Hydrology, 4, 442

How to obtain abundant clean energy, 2, 215

Humphry Davy on Geology: The 1805 Lectures for the General Audience, 3, 331

Inkohlung und Geothermik. Beziehungen zwischen Inkohlung, Illit-Diagenese,

Kohlenwasserstoff-Fuhrung und Geothermik, 4, 101

An Introduction to Ore Geology, 2, 221

Lower Cambrian Archeocyathid buildups, Pelly Mountains Yukon, 3, 326

Lunar Remote Sensing and Measurements. Apollo 15-17 Orbital Investigations, 2, 211

The Mammalian Skull, 6, 716

Mesozoic Mammals. The First two-thirds of Mammalian History, 2, 211

Metamorphic Rock Sequences of the Eastern Himalaya, 2, 217

Middle Ordovician to Lower Devonian Deep-Water Succession at southeastern margin of

Hazen Trough, Cañon Fiord, Ellesmere Island, 2, 218

Morphometric Methods in Biostratigraphy, 3, 324

Natural History Manuscript Resources in the British Isles, 4, 444

Oil sands, resource, recovery and industry, 4, 444

On Modeling Magnetic Fields on a Sphere with Dipoles and Quadrupoles, 6, 714

Ordovician and Silurian Phi Kappa and Trail Creek Formations, Pioneer Mountains,

Central Idaho - Stratigraphic and structural revisions, and new data on graptolite faunas, 3, 332

Petroleum and Hard Minerals from the Sea, 2, 216

Physical Geology, 2, 209

Physics of Magmatic Processes, 4, 443

Problems of Petroleum Migration, 3, 327

Quantitative Seismology, Theory and Methods, 2, 208

Reconnaissance geology of a part of the Precambrian Shield, Northwestern Quebec,

Northern Labrador and Northwest Territories, 2, 219

The Red Notebook of Charles Darwin, 3, 325

Remote Sensing in Geology, 4, 438

The Scientific Basis for Nuclear Waste Management, Volumes 1 and 2, 4, 430

Shear Zones in Rocks, 4, 444

Skeletal Growth of Aquatic Organisms. Biological Records of Environmental Change, 5, 572

The Solent Estuarine System. An Assessment of Present Knowledge, 4, 438

Stable Isotope Geochemistry, 2, 214

Stratigraphy and Correlation of Lower Paleozoic Formations, Subsurface of Bathurst Island, and adjacent smaller Islands, Canadian Arctic Archipelago, 2, 218 
Stratigraphy of part of the lunar Near Side, 6, 715

Structural framework of Lancaster Aulacogen, Arctic Canada, 2, 219

Studies in the Lateglacial of north-west Europe, 1, 104

A Trilobite zonation of Middle Ordovician rocks, Southwestern District of Mackenzie, 1, 101

Uranium and Nuclear Energy, 4, 432

Uranium Supply and Demand, 4, 429

Uses of Fieldwork in Further Education, 4, 434

Volcanic Activity and Human Ecology, 2, 212

Volcanic Scenery, 4, 437

\section{Publications Received}

Lists appear beginning pages 1,$109 ; 2,223 ; 3,333 ; 4,446 ; 5,577 ; 6,718$. 


\section{Index}

to Authors, key words in titles and to new taxa and new stratigraphical terms in Volume 118; $(\mathrm{R})$ indicates Review

Acharyya, S. K. Alkaline $v$ calc-alkaline Late Palaeozoic volcanism in the Himalayas and some aspects on Himalayan geotectonics, 421

Adighije, C. I. Gravity study of Lower Benue Trough, Nigeria, 59

Afghanistan (R), 433

Albian, nannofossils, Tunisia, 161

Al-Kadhi, A., Hancock, P. L. \& Al-Khatieb, S. O. Structural and photogeological evidence for the boundaries to an East Arabian block, 533

Allen, P. M. A new occurrence of possible Tertiary deposits in south-western Dyfed, 561

Ammonite, Coniacian, 557

Antarctic Peninsula, 139

Antiarch Biostratigraphy, 69

Appin Group, 477

Aquatic Organisms (R), 572

Archaean (R), 431

Archaeology (R), 106

Archeocyathid (R), 326

Arctic, Archipelago (R), 218; Canada (R), 219

Arc-trench system, 139

Ash-fall, 83

Atlantic-type continental margins (R), 332

Atmospheric Phenomena (R), 218

Au mineralization, 545

Bahat, Dov. Certain mechanical aspects in comparative continental rifting with a special reference to the Baikal rift, 271

Baikal rift, 271

Bailey, D. K: Bowen and the Post-Impressionists, 311

Baker, S. J. The graptolite biostratigraphy of a Llandovery outlier near Llanystumdwy, Gwynedd, North Wales, 355

Banham, P. H., Hopper, F.. M. W. \& Jackson, J. B. The Gillbrea Nappe in the Skiddaw Group, Cockermouth, Cumbria, England, 509

Barrington, 463

'Basalt Fingers', 251

Basaltic igneous activity, 27

Bassett, M. G. The Ordovician brachiopods of Cornwall, 647

Bathonian, 415

Bathurst Island (R), 218

Benton, M. J. \& Walker, A. D. The use of flexible synthetic rubbers for casts of complex fossils from natural moulds, 551

Benue Trough, Lower, 59

Bergamia artemis sp. nov., 630

Berkshire, 175 
Bhat, M. I., Zainuddin, S. M. \& Rais, A. Panjal Trap chemistry and the birth of Tethys, 367

Bideford, geology of (R), 574

Biosaline (R), 713

Biostratigraphy, 355; brachiopod, 385; (R), 324

Blackbourn, G. A. Correlation of Old Red Sandstone (Devonian) outliers in the Northern Highlands of Scotland, 409

Blårevbreen Sandstone Member, 231

Blue Anchor Formation, 377

Bohemilla tridens sp. nov., 638

Bowen, 311

Brachiopod biostratigraphy, 385

Brachiopods, British (R), 213; ordovician, 647

Bradbury, H. J. \& Graham, C. M. Cambrian and late Precambrian basaltic igneous activity in the Scottish Dalradian: a review, 27

Bradworthy (R), 105

Britain, South-west, 377

British Columbia (R), 713

Bude (R), 105

Butler, D. E. Marine faunas from concealed Devonian rocks of southern England and their reflection of the Frasnian transgression, 679

Calabria, 539

Calver, M. A. Palaeozoic studies in honour of Sir James Stubblefield, 581

Cambrian, Lower (R), 326; Scottish, 27

Cambridgeshire, 463; Great Paxton Borehole, 623

Cambro-Ordovician, 225

Campanian, phosphatic chalks and hardgrounds, 175

Carboniferous, 97; lower, 703

Cenomanian nannofossils, Tunisia, 161

Chalk, 557

Chalky till, 463

Chemical Heterogeneity (R), 329

China, Devonian, 69; 113; 385; Precambrian, 201; Primitive Man (R), 441

Chulmleigh (R), 105

Cirencester, 415

Coal ball, 307

Cockermouth, 509

Colley, H. \& Hindle, W. H. An oceanic volcano in an island arc setting - Seatura Volcano, Fiji, 1

Columnar joints, 251

Coniacian, ammonite, 557; phosphatic chalks and hardgrounds, 175

Connell, E. R. \& Hoare, P. G. The chalky till at Barrington, near Cambridge, and its connection with other Quaternary deposits in southern Cambridgeshire and adjoining areas, 463

Continental margins, 539; (R), 322

Continental rifting, 271

Cope, J. C. W. The Swansea Valley Fault, Wales, 309

Cornwall, Brachiopods, 647; Lizard peridotite, 491; Lower Devonian, 517

Correlation (R), 218 
Cretaceous, England, 175; Greenland, 337; nannofossils, Tunisia, 161 ; (R), 107

Cryptogenesis, 591

$\mathrm{Cu}$ mineralization, 545

Cyclopygacea, 603

Dalradian, 27; 477

Dalziel, I. W. D., Elliot, D. H., Jones, D. L., Thomson, J. W., Thomson, M. R. A., Wells, N. A. \& Zinsmeister, W. J. The geological significance of some Triassic microfossils from the South Orkney Islands, Scotia Ridge, 15

Dartmoor, 77

Dartmouth Beds, 517

Darwin, Charles (R), 325

Deep Drilling (R), 322

Deltaic Sand Bodies (R), 327

Devonian, China, 69; 113; 385; Ellesmere Island (R), 218; England, 679; Lower, 517; Scotland, 409

Diagenesis (R), 319; early (R), 330

Dicellograptus, mode of life, 401

Dinantian, 703

Dipoles (R), 714

Directional data, 39

District of Mackenzie (R), 101

Ditlovtoppen Dolomite Member, 234

Doushantuonema peatii sp. nov., 204

Duyverman, H. J. \& Roobol, M. J. Gas pipes in Eocambrian volcanic breccias, 265

Dyfed, 561

Earth (R), 220; (R), 320; Age of (R), 221

Earthquake Prediction (R), 321

Earthquakes (R), 432

Earth Science, dictionary (R), 324

Eastern Himalaya (R), 217

Egypt, 545

Ellesmere Island (R), 218

Elliot, D. H., Dalziel, I. W. D., Jones, D. L., Thomson, J. W., Thomson, M. R. A., Wells, N. A. \& Zinsmeister, W. J. The geological significance of some Triassic microfossils from the South Orkney Islands, Scotia Ridge, 15

Energy, alternative (R), 215; clean (R), 215

England, Devonian, 679; metamorphic rocks, 297; phosphatic chalks, 175 ; Skiddaw Group, 509; Tremadoc, 615

Eocambrian, 265

Estuaries (R), 435

Estuarine processes (R), 714

Ethiopia, geological map (R), 322

Europe, (R), 104; geology (R), 575

Evans, K. M. A marine fauna from the Dartmouth Beds (Lower Devonian) of Cornwall, 517

Evitt, W. R. \& Tripp, R. P. Silicified Lichidae (Trilobita) from the Middle Ordovician of Virginia, 665

Federal Republic of Germany (R), 434

Fieldwork, (R), 434 
Fiji, 1

Fjord Oceanography (R), 713

Forest Marble, 415

Fossils, casts, 551 ; (R), 103

Fossil Hunters (R), 571

Frasnian, 679

Gabbro, 525

Gale, A. S. \& Woodroof, P. B. A Coniacian ammonite from the 'Top Rock' in the Chalk of Kent, 557

Gas pipes, 265

Geochemical, 545

Geochemistry, Isotope (R), 214; (R), 209; Scotland, 477

Geological Howlers (R), 715

Geology and Scenery (R), 207

Geology, Atlas (R), 436; Bradworthy (R), 105; Bude (R), 105 ; Chulmleigh (R), 105; Europe (R), 575; Introduction (R), 320; New Zealand, 567; North of Derby (R), 439; ore (R), $221 ;(\mathrm{R}), 220$

Geotectonics, Himalayan, 421

Geothermik (R), 101

Germany, General Geology (R), 434

Gillbrea Nappe, 509

Gomez, B. \& Sims, P. C. Overbank deposits of the Narrator Brook, Dartmoor, England, 77

Gondwana, 139

Graham, C. M. \& Bradbury, H. J. Cambrian and late Precambrian basaltic igneous activity in the Scottish Dalradian: a review, 27

Graptolite, Llandovery, 355; Tremadoc, 615

Graptolithina, 401

Graptolitic facies, 566

Gravity, Benue Trough, 59

Great Paxton Borehole, Cambridgeshire, 623

Greenland, 337

Groundwater, (R), 208; (R), 442

Guadalcanal (R), 210

Gypsum crystals, 303

Hancock, P. L., Al-Khatieb, S. O. \& Al-Kadhi, A. Structural and photogeological evidence for the boundaries to an East Arabian block, 533

Hardgrounds, 175

Harland, W. B. Introducing New Zealand Geology, 567

Hazen, R. M. A Bibliography for Historians of Geology, 425

Hazen Trough (R), 218

Hemiarges turneri rasetti subsp. nov., 666

Higgins, A. C. \& Soper, N. J. Cretaceous-Palaeogene sub-basaltic and intrabasaltic sediments of the Kangerdlugssuaq area, Central East Greenland, 337

Highlands, northern, of Scotland, 409

Himalaya, Eastern (R), 217

Himalayas, 421

Hindle, W. H. \& Colley, H. An oceanic volcano in an island arc setting - Seatura Volcano, Fiji, 1 . 
Historians of Geology, 425

Hoare, P. G. \& Connell, E. R. The chalky till at Barrington, near Cambridge, and its connection with other Quaternary deposits in Southern Cambridgeshire and adjoining areas, 463

Hojjatzadeh, M. Mid-Cretaceous (Albian-Cenomanian) calcareous nannofossils from Pont du Fahs (northern Tunisia), 161

Holland, J. G., Lambert, R. St J. \& Winchester, J. A. Comparative geochemistry of pelites from the Moinian and Appin Group (Dalradian) of Scotland, 477

Holmes, J. \& Scott, A. C. A note on the' occurrence of marine animal remains in a Lancashire coal ball (Westphalian A), 307

Hopper, F. M. W., Banham, P. H. \& Jackson, J. B. The Gillbrea Nappe in the Skiddaw Group, Cockermouth, Cumbria, England, 509

Hou, H.-F. Devonian brachiopod biostratigraphy of China, 385

Hou, H.-F., Yang, S.-P. \& P'an, K. The Devonian System in China, 113

Howlers, Geological (R), 715

Hubei, 201

Hughes, C. P. \& Rushton, A. W. A. The Ordovician trilobite fauna of the Great Paxton Borehole, Cambridgeshire, 623

Human Ecology (R), 212

Humphry Davy (R), 331

Hydrography, Estuarine (R), 207

Hydrology (R), 442

Hydrothermal Ore (R), 209

Idaho (R), 332

Igneous rocks, 449

Indian lamprophyres, 393

Inkohlung (R), 101

Intrabasaltic sediments, 337

Iran, 49

Island arc, 1

Isotope Geochemistry (R), 214

Italy, southern, 539

Jackson, J. B. The Gillbrea Nappe in the Skiddaw Group, Cockermouth, Cumbria, England, 509

James, D. M. D. Petrographic evidence bearing on plate tectonics of the Upper Ordovician Welsh Basin, 95

Jarvis, I. \& Woodroof, P. The phosphatic chalks and hardgrounds of Boxford and Winterbourne, Berkshire - two tectonically controlled facies in the late Coniacian to early Campanian (Cretaceous) of southern England, 175

Johnson, M. R. W. The erosion factor in the emplacement of the Keystone thrust sheet (South East Nevada) across a land surface, 501

Jones, D. L., Dalziel, I. W. D., Elliot, D. H., Thomson, J. W., Thomson, M. R. A., Wells, N. A. \& Zinsmeister, W. J. The geological significance of some Triassic microfossils from the South Orkney Islands, Scotia Ridge, 15

Kangerdlugssuaq, 337

Kantha, L. H. 'Basalt fingers' - origin of columnar joints, 251

Kent, 557; coalfield, 703

Keystone thrust sheet, 501

Kiaerograptus? quasimodo sp. nov., 616 
Labrador, Precambrian (R), 219

Lambert, R. St J., Winchester, J. A. \& Holland, J. G. Comparative geochemistry of pelites from the Moinian and Appin Group (Dalradian) of Scotland, 477

Lamprophyres, Indian, 393

Lancashire, 307

Lancaster Aulacogen (R), 219

Lateglacial (R), 104

Leitch, E. C. Quartz-albite rocks of ash-fall origin, 83

Lichidae, Trilobita, 665

Lilleshall, Shropshire, 699

Lizard peridotite, 491

Llandovery, 355

Llanystumdwy, 355; Mudstone Formation, 355

Llŷn, 189

Ludlow Series, 566

Lunar, craters (R), 328; Near side, stratigraphy (R), 715; photogrammetry (R), 211; Remote Sensing (R), 211

Lundy Island, geology (R), 574

Magmatic Processes (R), 443

Magnetic Fields (R), 714

Majidi, B. The ultrabasic lava flows of Mashhad, North East Iran, 49

Mammalian Skull (R), 716

Mammals, Mesozoic (R), 211

Mantle, Chemical Heterogeneity (R), 329

Manuscript Resources, Natural History (R), 444

Mashhad, 49

Mason, R. A trondhjemite vein in the Sulitjelma Gabbro, Norway, and its implications for the age of the Sulitjelma Ophiolite, 525

Mayall, M. J. The Late Triassic Blue Anchor Formation and the initial Rhaetian marine transgression in south-west Britain, 377

Merlinia anxia sp. nov., 637

Mesozoic Mammals (R), 211

Metabasic rocks, 189

Metamorphic rocks, 297

Metamorphism, blueschistic, 539

Microfossil, Sinian, 201

Microfossils, 15

Micropalaeontological, 415

Mineral Deposits (R), 436

Minerals (R), 216; rock-forming (R), 106

Mitchell, M. The age of the Dinantian (Lower Carboniferous) rocks proved beneath the Kent Coalfield, 703

Mitchell, M. \& Reynolds, M. J. Early Tournaisian rocks at Lilleshall, Shropshire, 699

Moinian, 477

Morphometric Methods (R), 324

Mueilha - Dungash, 545

Nannofossils, calcareous, 161

Narrator Brook, 77

Natural History, Manuscript Resources (R), 444 
$\mathrm{Nb}$ mineralization, 545

Neotype, 565

Nevada, 501

Nigeria, 59

Northwest Territories, Precambrian (R), 219

Norway, 525; southern, 281

Nuclear Energy (R), 432

Nuclear Waste (R), 430

Ny Friesland, 225

Oceanic, 1

Oceanography, Fjord (R), 713

Ogygiocaris macrops sp. nov., 635

Oil sands (R), 444

Olaussen, S. Marine incursion in Upper Palaeozoic sedimentary rocks of the Oslo Region, Southern Norway, 281

Old Red Sandstone, Scotland, 409

Ontario (R), 431

Ophiolite, 525

Ordovician, brachiopods, 647; Ellesmere Island (R), 218; Idaho (R), 332; Llŷn \& Snowdonia, 189; Middle (R), 101; trilobite, 89, 623; Virginia, 665; Welsh Basin, 95

Ore, Deposits (R), 209; Geology (R), 221

Oscillatoriaceae, 201

Oslo Region, 281

Overbank deposits, 77

Overthrusting, 539

Owens, R. M. The Ordovician proetacean trilobite Rorringtonia, 89

Paedomorphosis, 591

Palaeogene, 337

Palaeotectonic, 225

Palaeozoic, 581; late, 421; Upper, 281 ; Volcanism, 421

Paleoecology (R), 103

Paleozoic (R), 218

Panjal Trap, 367

P'an K. Devonian Antiarch Biostratigraphy of China, 69

P'an K., Yang, S.-P. \& Hou, H.-F. The Devonian System in China, 113

Paul, D. K. \& Potts, P. J. Rare earth abundances and origin of some Indian lamprophyres, 393

Pelly Mountains (R), 326

Peridotite, Lizard, 491

Petroleum, Migration (R), 327; (R), 216

Phi Kappa Formation (R), 332

Phosphatic chalks, 175

Photogrammetry (R), 211

Physical Geology (R), 209

Piccarreta, G. Deep-rooted overthrusting and blueschistic metamorphism in compressive continental margins. An example from Calabria (Southern Italy), 539

Pioneer Mountains (R), 332

Plants, Ancient (R), 571

Plate tectonics, Welsh Basin, 95 
Pont du Fahs, 161

Potts, P. J. \& Paul, D. K. Rare earth abundances and origins of some Indian lamprophyres, 393

Precambrian, China, 201; Quebec, Labrador \& Northwest Territories (R), 219; Scottish, 27

Price, D. Tretaspis radialis Lamont and allied species (Trilobita), 289

Primitive Man, China (R), 441

Proetacean trilobite, 89

Prospectatrix genatenta, 603

Protolloydolithus salax sp.nov., 631

Quadrupoles (R), 714

Quartz-albite rocks, 83

Quaternary, 463

Quebec, Precambrian (R), 219; (R), 431

Rais, A., Bhat, M. I. \& Zainuddin, S. M. Panjal Trap chemistry and the birth of Tethys, 367

Rare earth, 393

Red Notebook (R), 325

Remote Sensing, Lunar (R), 211 ; (R), 438

Resources (R), 713

Retepora nodulosa, 565

Reȳnốús, M. J. \& Mitche!!, M. Early Tournaisian rocks at Lilleshall, Shropshire, 699

Rhaetian, 377

Roberts, B. Low grade and very low grade regional metabasic Ordovician rocks of Llŷn and Snowdonia, Gwynedd, North Wales, 189

Robinson, D. Metamorphic rocks of an intermediate facies series juxtaposed at the Start boundary, southwest England, 297

Rock, N. M. S. How should igneous rocks be grouped?, 449

Rocks, metamorphic (R), 217

Roobol, M. J. \& Duyverman, H, J. Gas pipes in Eocambrian volcanic breccias, 265

Rorringtonia, 89

Rorringtonia kennedyi sp. nov., 91

Rothstein, A. T. V. The primary crescumulates of the Lizard peridotite, Cornwall, 491

Rushton, A. W. A. A polymorphic graptolite from concealed Tremadoc rocks of England, 615

Rushton, A. W. A. \& Hughes, C. P. The Ordovician trilobite fauna of the Great Paxton Borehole, Cambridgeshire, 623

Rydon Member, 377

Sand grains, 303

Scenery, volcanic (R), 437

Schalidomorthis stubblefieldi sp. nov., 650

Scotia Ridge, 15

Scotland, geochemistry, 477; Highlands, 409; (R), 207

Scott, A. C. \& Holmes, J. A note on the occurence of marine animal remains in a Lancashire coal ball (Westphalian A), 307

Seatura Volcano, 1

Sedimentary rocks, 281 ; (R), 319

Sedimentation, estuarine (R), 207

Sediments (R), 319

Segmentagnostus stubblefieldi sp. nov., 627 
Seismicity patterns $(\mathrm{R}), 321$

Seismology (R), 208

Shakesby, R. A. The application of trend surface analysis to directional data, 39

Shearman, D. J. Displacement of sand grains in sandy gypsum crystals, 303

Shear Zones (R), 444

Shropshire, Lilleshall, 699

Silurian, Idaho $(R), 332$

Sims, P. C. \& Gomez, B. Overbank deposits of the Narrator Brook, Dartmoor, England, 77

Sinian, 201

Skeletal growth (R), 572

Skiddaw Group, 509

Smellie, J. L. A complete arc-trench system recognized in Gondwana sequences of the Antarctic Peninsula region, 139

Sn mineralization, 545

Snowdonia, 189

Solent Estuarine System (R), 438

Soliman, M. M. Geochemical surveys for $\mathrm{Sn}, \mathrm{Nb}, \mathrm{Cu}$ and $\mathrm{Au}$ mineralization, MueilhaDungash area, Southeastern Desert, Egypt, 545

Solomon Islands (R), 210

Somalia, geological map (R), 322

Soper, N. J. \& Higgins, A. C. Cretaceous-Palaeogene sub-basaltic and intrabasaltic sediments of the Kangerdlugssuaq area, central east Greenland, 337

South Orkney Islands, 15

South Wales, 97

Spitsbergen, 225

Start boundary, 297

Stratigraphy, Lunar near side (R), 715; (R), 218

Stromatolite, subaerial, 97

Stubblefield, Sir James, 581

Sub-basaltic sediments, 337

Sulitjelma Gabbro, ophiolite, 525

Swansea Valley Fault, 309

Swett, K. Cambro-Ordovician strata in Ny Friesland, Spitsbergen and their palaeotectonic significance, 225

Synthetic rubbers, 551

Taphonomy (R), 103

Tavener-Smith, R. The neotype of Retepora nodulosa Phillips, 1836, 565

Tertiary, 561

Tethys, 367

Thomson, J. W., Dalziel, I. W. D., Elliot, D. H. , Jones, D. L., Thomson, M. R. A., Wells, N. A. \& Zinsmeister, W. J. The geological significance of some Triassic microfossils from the South Orkney Islands, Scotia Ridge, 15

Timmins-Kirkland Lake-Noranda (R), 431

Topiggane Shale Member, 232

Top rock, 557

Tournaisian, 699

Trail Creek Formations (R), 332

Tremadoc, 615

Trend surface analysis, 39 
Tre-Nichol Formation, 561

Tretaspis, caritus sp. nov., 292; radialis, 289

Triassic, $15 ; 377$

Trilobita, 289; Lichidae, 665

Trilobite, Ordovician, 623; Rorringtonia, 89; Zonation (R), 101

Trilobites, 591

Trinucleus bicallis sp. nov., 628

Tripp, R. P. \& Evitt, W. R. Silicified Lichidae (Trilobita) from the middle Ordovician of Virginia, 665

Trondhjemite, 525

Tunisia, 161

Ultrabasic lava flows, 49

Uranium, Deposits (R), 429; Supply (R), 429; Nuclear Energy (R), 432

Virginia, Ordovician, 665

Volcanic, Activity (R), 212; breccias, 265; scenery (R), 437

Volcanism, Palaeozoic, 421

Wales, 189 ; 309; North, 355

Walker, A. D. \& Benton, M. J. The use of flexible synthetic rubbers for casts of complex fossils from natural moulds, 551

Ware, M. \& Windle, T. M. F. Micropalaeontological evidence for land near Cirencester, England, in Forest Marble (Bathonian) times: a preliminary account, 415

Wells, N. A., Dalzie!, I. D., Elliot, D. H., Jones, D. L., Thomson, J. W., Thomson, M. R. A. \& Zinsmeister, W. J. The geological significance of some Triassic microfossils from the South Orkney Islands, Scotia Ridge, 15

Welsh Basin, 95

Westphalian A, 307

Wetland processes $(R), 714$

White, D. E. The base of the Ludlow Series in the graptolitic facies, 566

Whittington, H. B. Paedomorphosis and cryptogenesis in trilobites, 591

Williams, S. H. Form and mode of life of Dicellograptus (Graptolithina), 401

Williton Member, 379

Winchester, J. A., Lambert, R. St J. \& Holland, J. G. Comparative geochemistry of pelites from the Moinian and Appin Group (Dalradian) of Scotland, 477

Windle, T. M. F. \& Ware, M. Micropalaeontological evidence for land near Cirencester, England, in Forest Marble (Bathonian) times: a preliminary account, 415

Woodroof, P. B. \& Gale, A. S. A Coniacian ammonite from the 'Top Rock' in the Chalk of Kent, 557

Woodroof, P. B. \& Jarvis, I. The phosphatic chalks and hardgrounds of Boxford and Winterbourne, Berkshire - two tectonically controlled facies in the late Coniacian to early Campanian (Cretaceous) of southern England, 175

Wright, V. P. A subaerial stromatolite from the Lower Carboniferous of South Wales, 97

Yang, S.-P., P'an, K. \& Hou, H.-F. The Devonian System in China, 113

Yukon (R), 326

Zainuddin, S. M., Bhat, M. I. \& Rais, A. Panjal Trap chemistry and the birth of Tethys, 367

Zhang. Z. A new Oscillatoriaceae-like filamentous microfossil from the Sinian (late Precambrian) of western Hubei Province, China, 201

Zinsmeister, W. J., Dalziel, I. W. D., Elliot, D. H., Jones, D. L., Thomson, J. W., Thomson, M. R. A. \& Wells, N. A. The geological significance of some Triassic microfossils from the South Orkney Islands, Scotia Ridge, 15 
Contributions for publication should be addressed to The Editors, Geological Magazine, Department of Earth Sciences, Downing Street, Cambridge CB2 3EQ, England.

All contributions, whether articles, correspondence or reviews, must be typed in duplicate on one side of the paper, double spaced throughout, with a wide margin on the left of each page and a narrower margin on the right. Any minor corrections should be made neatly in the typescript, leaving the margins clear.

The total length of a paper should not in general exeeed 20 pages of the Geological Magazine; preference and priority are given to short papers. Longer papers (between 20 and 40 pages of Geological Magazine) will from time to time be considered, but authors wishing to submit such manuscripts should first request further details.

The accuracy of references is the responsibility of authors. References must be double spaced and abbreviated in the form of the World List of Scientific Periodicals 4th Edition as far as possible, e.g.

Brooks, M. \& James, D. G. 1975. The geological results of seismic refraction surveys in the Bristol Channel, 1970-73. Q. Fl geol. Soc. Lond. 131, 163-82.

Kirby, G. A. 1978. Layered gabbros in the Eastern Lizard, Cornwall, and their significance. Geol. Mag. 115, 199-204.

Books should be cited as:

Ramsey, J. G. 1967. Folding and Fracturing of Rocks. New York: McGraw-Hill.

Bott, M. H. P. 1973 The evolution of the Atlantic north of the Faroe Islands. In Implications of Continental Drift to the Earth Sciences, vol. 1 (ed. D. H. Tarling and S. N. Runcorn), pp. 175-89. London, New York: Academic Press.

Unpublished work, e.g. from theses, should normally be referred to in the text in parentheses and not included in the reference list unless in the press.

Articles must be accompanied by a brief summary. Contributions should follow the general style of papers in recent issues of the Magazine and the principles laid down in Notes to Authors (Proc. Geol. Soc. Lond., No. 1627. Oct. 1965). Headings should be set out clearly, but not underlined. Primary headings should be in lower case, at margin, with arabic numeral; sub-headings should be numbered 2.a, 2.b, etc., and tertiary headings 2.a.1., 2.a.2. No cross-references should be given by page number, but 'above' and 'below' should be used with the section specified, e.g. Section 2.a.1.

Illustrations must be drawn to allow reduction to maximum size of $200 \mathrm{~mm} \times$ $134 \mathrm{~mm}$; originals should normally be drawn at twice final size and must be sent in a flat package. Lettering must allow for legibility after reduction (i.e. equivalent to $1 \mathrm{~mm}$ as a minimum on reduction). Duplicates of illustrations may be prints or, preferably, reductions. Metric units of the SI system are preferred. Illustrations in the text will be referred to as figures (Fig. 2, $2 a$, etc.), and halftone plates will be referred to (also in arabic) as Plates 2, $2 a$, etc. Folding plates will not be accepted. Captions for figures and plates must be typed on separate sheets.

Twenty-five offprints of each paper will be provided free of charge. Additional offprints may be purchased according to a set scale of charges. 


\section{Geological Magazine}

\section{Volume 118, Number 6, November 1981}

CALVER, M. A.

Palaeozoic studies in honour of Sir James Stubblefield

$5^{81-589}$

WHITTINGTON, H. B.

Paedomorphosis and cryptogenesis in trilobites

$59^{1-602}$

FORTEY, R. A.

Prospectatrix genatenta (Stubblefield) and the trilobite superfamily Cyclopygacea

$603-614$

RUSHTON, A. W. A.

A polymorphic graptolite from concealed Tremadoc rocks of England

$615-622$

RUSHTON, A. W. A. \& HUGHES, C. P.

The Ordovician trilobite fauna of the Great Paxton Borehole, Cambridgeshire

$623-646$

BASSETT, MICHAEL, G.

The Ordovician brachiopods of Cornwall

$647-664$

TRIPP, R. P. \& EVITT, W. R.

Silicified Lichidae (Trilobita) from the Middle Ordovician of Virginia

$665-677$

BUTLER, D. E.

Marine faunas from concealed Devonian rocks of southern England and their reflection of the Frasnian transgression

MITCHELL, M. \& REYNOLDS, M. J.

$699-702$

Early Tournaisian rocks at Lilleshall, Shropshire

MITCHELL, M.

$703-711$

The age of the Dinantian (Lower Carboniferous) rocks proved beneath the Kent Coalfield

REVIEWS

PUBLICATIONS RECEIVED

(C) Cambridge University Press 1981

Printed in Great Britain at the University Press, Cambridge 